Vantage: Journal of Thematic Analysis

ISSN: 2582-7391

A Multidisciplinary Publication of Centre for Research,

Maitreyi College, University of Delhi

April 2021, Volume 2, Issue 1

Book Review

\title{
And We Came Outside and Saw the Stars Again: Narratives of Courage and Resilience
}

\author{
Rose Mittal
}

Department of English, Maitreyi College, University of Delhi, Chanakyapuri,

New Delhi-110021, India

*Correspondence: rose.mittal7@gmail.com

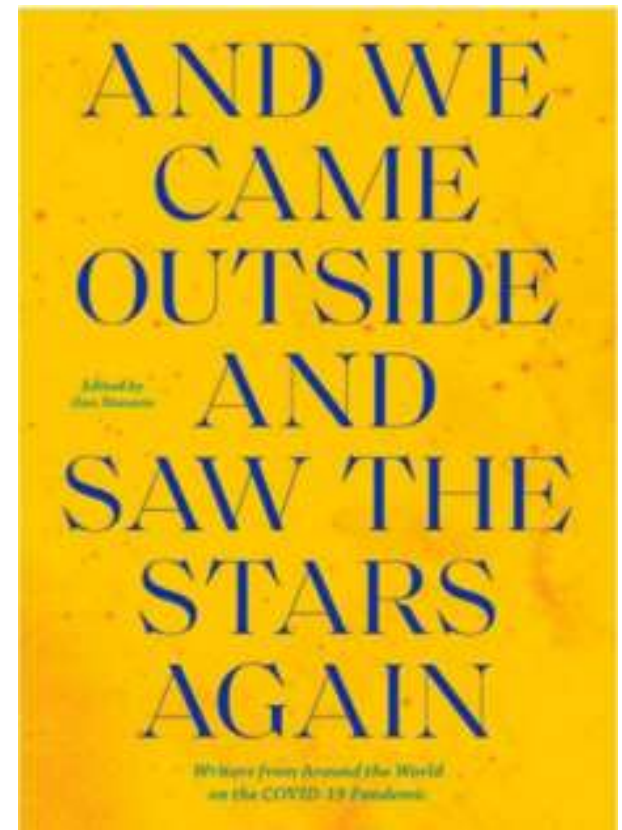

Stavans, Ilan. And We Came Outside and Saw the Stars Again. 2020. India:

Penguin Random House, 2020

Civilization began around fire. The world's governments should know that it served three essential purposes: warming hands, cooking, and telling stories.

( 'The Parable of Bread', And We Came Outside and Saw the Stars Again)

And We Came Outside and Saw the Stars Again is a breath of fresh air in this world, contaminated by the coronavirus. At a time when stepping outside the house is a crime, travelling is a far cry. With this book, Ilan Stavans empowers the readers with wings and 
takes them on a refreshing voyage by enabling them to travel to more than thirty foreign lands to peep into the lives of ordinary men and women, and witness their diverse reactions, struggles and coping mechanisms to the COVID-19 pandemic. On this journey the readers are compelled to delve into some of the deeper questions of life and are exposed to a spectrum of realities which co-exist in a world facing a common challenge. All these ideas are packed into assorted forms of literary dispatches from letters, stories, personal essays, poems, opinion pieces, artwork to graphic memoirs, thereby targeting a general readership and appealing to people with differing tastes.

More than fifty writers have contributed to this anthology, representing thirty-five countries. Experiencing different writing styles is the highlight of this book that traverses diverse cultures, filling the readers with both wonder and admiration at the same time. The title of this book promises the audience tales of optimism which the book successfully delivers in addition to offering pieces capturing many other sentiments like misery, confusion, faith, love, empathy and the plague that is paranoia. Loneliness somehow dominates the experiences these writers have as a result of the lockdown but by the time one finishes reading the book, one realizes that loneliness paradoxically binds people across the globe together since no one is alone in their loneliness after all.

The most impactful thing about this collection is its ability to make the readers push the limitations of their minds to invite a range of different perspectives when people struggle with similar things. Shenaz Patel from Mauritius realizes that we are in the middle of a 'civil war' of speech between those who respect the lockdown and the 'cocovids' (those who knowingly put others in danger). The only point of commonality between the two types seems to be that we all continue to live our lives as birds, "small, fragile, stubborn, hopeful, nest-weaving, breeze-seeking, soaring in bright and fleeting swarms" (8). Frederika Randall from the United States, on the other hand, is suspicious of the birds who seem to mock her and scale her residence, peeping through the windows as if planning an invasion in her territory, just like her species have done to millions of species that once inhabited the planet freely. She wonders if the viral video clips of wildlife like elephants, lions and flamingoes crossing the borders of their confinement, marked by fear of humans, are finally reclaiming their lost space while humans are shut up indoors, 
finishing with an intriguing conclusion that both the virus and human beings need to spend some time worrying about others.

The book also touches upon the historical and political discussions that COVID-19 has brought forth. Lilya Kalaus from Kazakhstan draws surprising yet befitting parallels between life in quarantine and life in middle-ages as she talks about her everyday chores, impelling the readers to ponder upon the degree to which the world has regressed. Juan Villoro from Mexico expresses his concern over cuts made on the funding of the cultural sector by governments all across the world. He points that people are surviving the crisis, 'thanks to arts' and claims that imagination is the key to get us through the pandemic. Our escape from mental imprisonment by sharing memes and tweets, reciting poetry, singing, talking over the phone or Skype, dreaming and listening to the dreams of others, is probably the strongest evidence that "man cannot live by bread alone" (226). Khalid Albaih from Sudan, in his brilliant essay, takes a dip into the pool of irony as he amusingly observes how the first world is coping with the pandemic. In a rhetorical apology he confesses that the 'new normal' of the world has been the 'old normal' for billions of Brown and Black people all around the world. The outrageous scrutiny that these coloured people are incessantly subjected to is often 'rationalized' by suspecting them to be participating in terrorist activities or possessing curious diseases. The hard truth that most people from these countries are not able to travel to the destinations of their choice, sometimes because they cannot afford to and other times simply because of declared and undeclared travel restrictions on account of suspicion, made the lives of common people distressing, even before the corona virus sprang into the picture that affects the first world.

Several pieces in the collection tread upon the thin line between utopia and dystopia. We dream of a peaceful relaxing holiday in this exhausting work culture, an ideal when realized, terrorizes us. The book is enriched with several confessional pieces laying bare the immensely relatable struggles of the writers, which feel like a hug of condolence in the world where we now practice social distancing. A man protecting his son from the despondency of the pandemic who misses rolling in the sand box, a woman running away horrified from an old lady who coughed on her while standing in a queue, a poet flirting with the 'song and silence' that is the lockdown, a person who saved an ant when blessed 
with the gift of time...These are the stories of ordinary people offering a shoulder to lean on at a time when people hold their breath when someone passes by.

From making the readers go back to the screenshots of the parties which once used to be photographs, to making them laugh over the poor COVID-19 who finally earned fame in the virus community years after its discovery, the book is a gem of relatable experiences mixed with irony, wistfulness and humour that induces hope and a fresh outlook on life in the readers and continues to remain with them long after they have turned the final page of the book. It is no wonder that this book by Stavans, a renowned literary figure, has been gaining critical acclaim as well as popularity worldwide.

How to cite this article: Mittal, R. (2021). And We Came Outside and Saw the Stars Again: Narratives of Courage and Resilience. Vantage: Journal of Thematic Analysis, 2(1): 121-124.

DOI: https://doi.org/10.52253/vjta.2020.v02i01.09

(C) The Author(s) 2021.

This work is licensed under a Creative Commons Attribution 4.0 International License which permits its use, distribution and reproduction in any medium, provided the original work is cited. 